"I' $m$ stuck, I'm right in the middle of it, I can't get out. about a half mile east of Drake on the highway. Get the cars out of the low area down below.

T ast words received from Sergeant Willis Hugh Purdy, Colorado State Patrol. Sergeant Purdy was a victim and a hero of the Big patchers informed him of severe weather problems in the Big Thompson Canyon. As Purdy proceeded into the canyon, he ordered the evacuation of the lower areas below the canyon, a decision that saved hundreds of lives. Purdy was posthumously awarded the Colorado State Patrol Medal of Valor. Two years later, a memorial was dedicated in the Big Thompson Canyon, which is located about 1.3 miles downstream from Drake, honoring Sergeant Purdy and Estes Park Officer Michael Conley.

(Courtesy of The Colorado Law Enforcement Memorial Book Online; http://www.csp. state.co.us/academy/ acfallen.htm)

\title{
Introduction
}

In the early evening of Saturday, July 31, 1976, a large stationary thunderstorm released as much as 7.5 inches of rainfall in about an hour (about 12 inches in a few hours) in the middle reaches of the Big Thompson River Basin and to a lesser extent in parts of the Cache la Poudre River Basin (U.S. Geological Survey, 1979). In steep mountain terrain with thin or no soil, this large amount of rainfall in such a short period of time produced a flash flood that caught residents and tourists by surprise. The sudden flood that churned down the narrow Big Thompson Canyon scoured the river channel that night, caused over $\$ 35$ million in damages (1977 dollars) to 418 homes and businesses, many mobile homes, 438 automobiles, numerous bridges, paved and unpaved roads, power and telephone lines, and many other structures. The tragedy claimed the lives of 144 people, including two law enforcement officers trying to evacuate people in danger, and there were 250 reported injuries (U.S. Geological Survey, 1979). Scores of other people narrowly escaped with their lives. More than 800 people were evacuated by helicopter the following morning.

July 2006 revisits the $30^{\text {th }}$ anniversary of the Big Thompson floodone of the most deadly flash floods in Colorado's recorded history (Jarrett and Vandas, 2006). Many residents and visitors who were present in the Big Thompson Canyon on July 31, 1976, recall the flood with vivid memories. This fact sheet presents a summary of the hydrologic conditions of the 1976 flood, describes some of the advances in U.S. Geological Survey (USGS) flood science as a consequence of this disaster, and provides a reminder that extreme floods like the 1976 Big Thompson flood have occurred in other locations in Colorado in the past and will occur again. The USGS conducts research and operates a Nationwide streamgage network to help understand and predict the magnitude and likelihood of large streamflow events such as the Big Thompson flood.

Figure 1. Digital Elevation Model (DEM) perspective view with draped digital orthophotography of the middle Big Thompson Canyon and surrounding area. Modified from Jarrett and Vandas (2006). Image created by Paco Van Sistine, USGS.

\section{The Flood}

A complex system of thunderstorms produced intense rainfall from about 6 to 7 pm (MDT) on July 31, 1976, in the Front Range foothills of Colorado's Big Thompson River (fig. 1) and Cache la Poudre River Basins in Larimer County. This Saturday night marked the eve of Colorado's $100^{\text {th }}$ anniversary of Statehood, and at the height of the tourist season an estimated 3,500 people were enjoying the cool beauty and recreation of the mountain canyons, unaware of the unusual and unique atmospheric conditions that were occurring.

The topography of the affected area is characterized by narrow canyons bordered by steep, rocky, mountain slopes (fig. 1). On July 31, 1976, a moist airmass began pushing westward from the Great Plains on the east side of the Rockies. During the afternoon, the moist air rose up the mountain slopes and the unstable air began to build into thunderstorms; a schematic illustration showing the cause of the storm and flood is provided in figure 2. Large thunderstorms formed along the Front Range and began to dump heavy rain on the region about 6:30 p.m. This event turned deadly when high-altitude westerly winds, which are usually strong enough to push thunderstorms eastward and out of the area, were unusually weak. The thunderstorms stalled for more than 3 hours over the Big Thompson Canyon, and built into a gigantic thunderstorm system. The thunderstorms produced as much as 12-14 inches of 
in from July 31 to August 1 (fig. 3), although most rain
ell in the first $4-6$ hours (U.S. Geological Survey, 1979). The total rainfall from this event is nearly equivalent to ear's average annual precipitation in this area. To place the infrequent nature of the 1976 rainstorm amounts in perspective, the 100-year, 6-hour duration rainfall is abo
3 inches in the area of heaviest rinfall (htto gov). The storm was limited to a narrow band 5-10 miles wide extending from just southeast of Estes Park (fig. 3) northward to the Wyoming border. The storm was located just east and downstream from Olympus Dam in Estes Prime bout 7.5 inches of rain fell in about 70 minutes near Glen Comfort in the heart of the canyon below Estes Park, turning the normally placid Big Thompson River and tributaries so a raging to higher ground before cars, roads, trees, and buith ings were damaged or washed away. in and downstream from the storm's rainfall center. The peak discharge estimated dite streamflow-gaging station canyon near Drake was $31,200 \mathrm{ft}^{3 / 3} / \mathrm{s}$ (cubic feet per seconde this was almost 4 times the previous maximum discharge of $8,000 \mathrm{ft} / \mathrm{s}$ since record keeping began in 1887 (table 1 ). River depths went from a few feet to nearly 20 feet, and reaches of the Big Thompson Canyon (fig. 4). The peak dis-
resured charges for three tributaries near the area of heaviest rain exceeded previously recorded maximum discharges for
basins less than 4 square miles in Colorado (U.S. Geologic

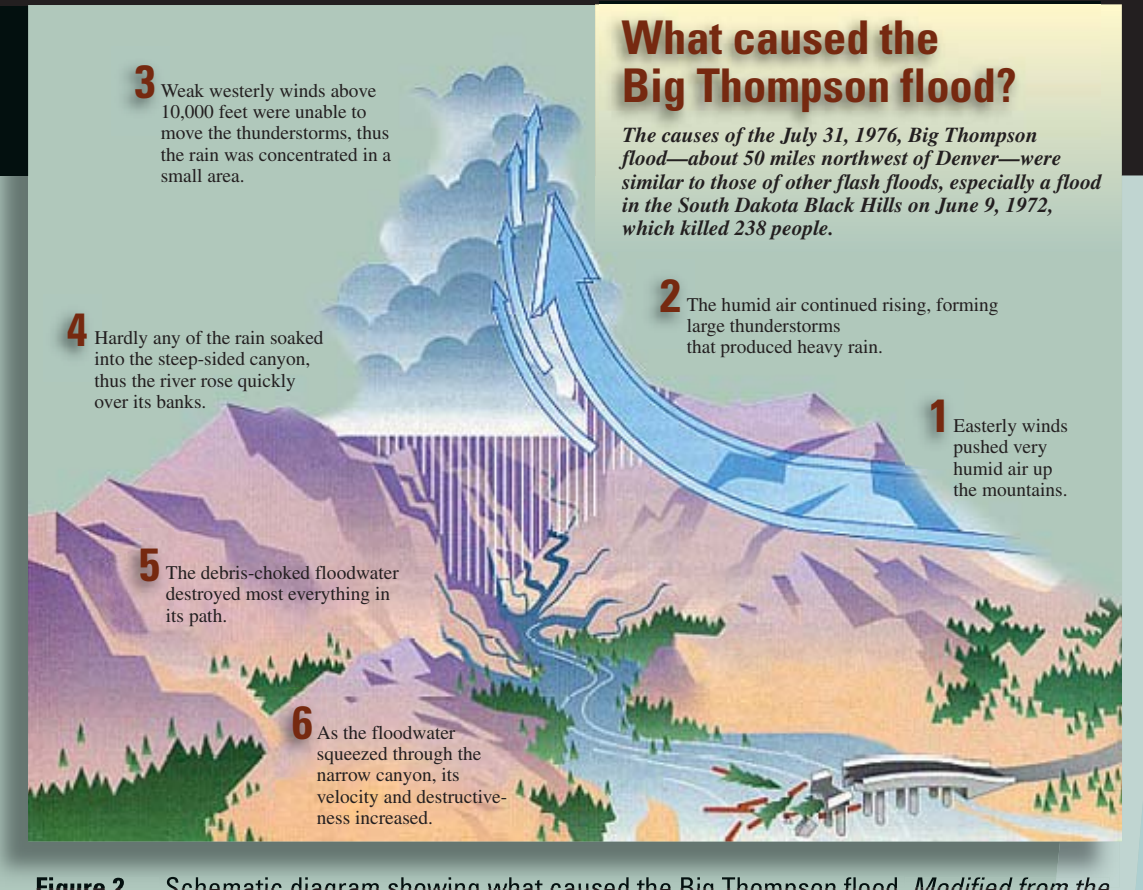

Figure 2. Schematic diagram showing what caused the Big Thompson flood. Modified from the

Survey, 1979). Flood recurrence intervals were far in excess of the estimated 100-year 10,000 years ago (Jarrett and Costa 1988) Spatial variability of ruo of watciss about the Big Thompson River at the Estes Park gage, the peak discharge of $457 \mathrm{ft}^{3} / \mathrm{s}$ table 1) was less than a 2-year flood. Once the floodwaters flowed into the wide floodplain downstream from the mouth of the Big Thompson Canyon, attenuation reduced the peak River at the confluence with the South Platte River (toble 1). The flood in the Cache northwest of Fort Collins; flood damage was less extensive and, fortunately, no deaths
Table 1. Comparison of 1976 peak discharges with other peak discharges for selected current (2006) U.S. Geological Survey and Colorado Department of Water Resources streamflow-gaging stations and miscellaneous [--, not applicable or no data.]

\begin{tabular}{|c|l|}
\hline $\begin{array}{c}\text { Site identifier } \\
\text { (see. fig. 3) }\end{array}$ & \multicolumn{1}{|c|}{ Station name } \\
\hline A & $\begin{array}{l}\text { Big Thompson River below } \\
\text { Moraine Park near Estes Park }\end{array}$ \\
\hline B & $\begin{array}{l}\text { Big Thompson River at } \\
\text { Estes Park ( }\end{array}$ \\
\hline C & $\begin{array}{l}\text { Big Thompson River tributary } \\
\text { below Loveland Heights }\end{array}$ \\
\hline D & Big Thompson River above Drake \\
\hline E & $\begin{array}{l}\text { North Fork Big Thompson River } \\
\text { tributary near Glen Haven }\end{array}$ \\
\hline F & $\begin{array}{l}\text { North Fork Big Thompson River } \\
\left.\text { at Drake ( }{ }^{(}\right)\end{array}$ \\
\hline G & $\begin{array}{l}\text { Big Thompson River at mouth of } \\
\left.\text { Canyon, near Drake ( }{ }^{(}\right)\end{array}$ \\
\hline H & $\begin{array}{l}\text { Big Thompson River at mouth, } \\
\left.\text { near LaSalle ( }{ }^{(}\right)\end{array}$ \\
\hline
\end{tabular}

\begin{tabular}{|r|c|c|c|c|}
\hline \multirow{2}{*}{ Station number } & \multirow{2}{*}{$\begin{array}{c}\text { Drainage area } \\
\left(\mathbf{m i}^{2}\right)^{b}\end{array}$} & \multicolumn{3}{|c|}{ Peak flows before July 1976 } \\
\cline { 3 - 6 } & & Period of record & Year & $\begin{array}{c}\text { Streamflow } \\
\left(\mathbf{f t}^{3} \mathbf{s}\right)\end{array}$ \\
\hline 402114105350101 & 39.8 & $\begin{array}{c}1996-97 \\
2001-06\end{array}$ & -- & -- \\
\hline 06733000 & 137.0 & $1946-76$ & 1949 & 1,660 \\
\hline none & 1.4 & -- & -- & -- \\
\hline none & $189(34)$ & -- & -- & -- \\
\hline none & 1.4 & -- & -- & -- \\
\hline 06736000 & 85.1 & $1947-76$ & 1965 & 1,290 \\
\hline 06738000 & $305(150)$ & $1887-76$ & 1919 & 8,000 \\
\hline 06744000 & $828(673)$ & $1914-15$ & $1927-76$ & 6,100 \\
\hline
\end{tabular}

\begin{tabular}{|c|c|c|}
\hline \multirow{2}{*}{$\begin{array}{c}\begin{array}{c}\text { Flood of July 31, } \\
1976\end{array} \\
\text { Streamflow (ft3/s) }\end{array}$} & \multicolumn{2}{|c|}{ Peak flows after July 1976} \\
\hline & Date & $\begin{array}{c}\text { Streamflow } \\
\left(\begin{array}{c}\left.\mathrm{tt}^{3} / \mathrm{s}\right)\end{array}\right.\end{array}$ \\
\hline-- & 05-31-2003 & 828 \\
\hline 457 & 06-18-1995 & $1,870\left(^{(}\right)$ \\
\hline 8,700 & -- & -- \\
\hline 28,200 & -- & -- \\
\hline 9,670 & -- & - \\
\hline 8,710 & 05-30-1995 & 572 \\
\hline 31,200 & 04-30-1980 & 6,150 \\
\hline 2,440 & 05-31-1995 & 6,710 \\
\hline
\end{tabular}

:Operated by Colorado Department of Water Resources.

'Where known, 1976 estimated contributing drainage areas are shown in parentheses.
"Peak discharge was 5,500 ft'/s from the 1982 Lawn Lake dam failure.
Probably the most destructive components during the flood were floodwater velocities, and the maximum flood depths. Average stream velocities as much as $20-25$ feet per second were common in narrow constricted tributaries and canyons. These high velocities resulted in (t) 政 cal Survey, 1979). The sudden nighttime storm caught most people by conditions, and some people were unclear about what toophic flood made after the flood showed that people who climbed to higher in the canyon had the greatest chance of surviving the flood, whereas hose who attempted to escape in automobiles through the canyon were What did the Big Thompson flood and USGS flood science teach us bout flash floods?

If you tried to escape the flood in a car or stayed in homes or motels located in the floodplain, the chance of death increased substantially.
Many roads followed the n and evacuating in a car often led people directly into the path of the
raging water, which washed raging water, which washed out many roads. New signage after
flood cautions people to climb to safety in the event of a flood.

- People underestimate the power of swift-flowing water. It is also easy depth of only $1-2$ feet is dangerous to walk through and can push or the river channel and to near certain destruction
Flass floods occur along the Front Range nearly exclusively below alti-
tudes of about 7.500 feet. Floods at higher altitudde are generated primarly by snowmelt runoff in the springtime (Jarrett and Costa, 1988). - A flood produced by as much rain as occurred during the 1976 flood over such a large areal extent in the Big Thompson River and Cache la Poudre
River Basins is rare. Based on radiocarbon dating of ancient flood deposhe 1976 flood has not occurred in the Big Thompson Canyon for several thousa
1977; Simons and others, 1978; Jarrett and Costa, 1988).

It is important to differentiate debris flows, which can be initiated by
modest rainfall or only snowmelt, from intense rainfall-produced floods. dhe largest flow events in small basins at high altitude in Colorado were not water floods, yet these events had been erroneously thought to have been produced by tha discharge of water floods are lows, which lead to substantial over-estimation of the magnitude of peak discharge of the flow (Costa and Jarrett, 1981).

- Estimates of peak flow discharge in small steep basins can have great
uncertainty. The largest problems are estimation of roughness of stream

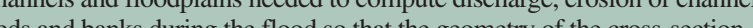
during the peak is unknown, and the unsteady nature of large dischargrges in higher gradient channels (Jarrett, 1987.

Many Colorado communities, particularly in the western Denver-Boul-
der metropolitan area, are at risk from flash floods. They are in setting

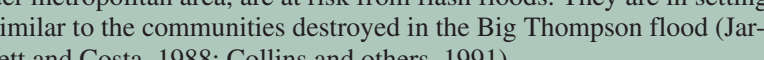

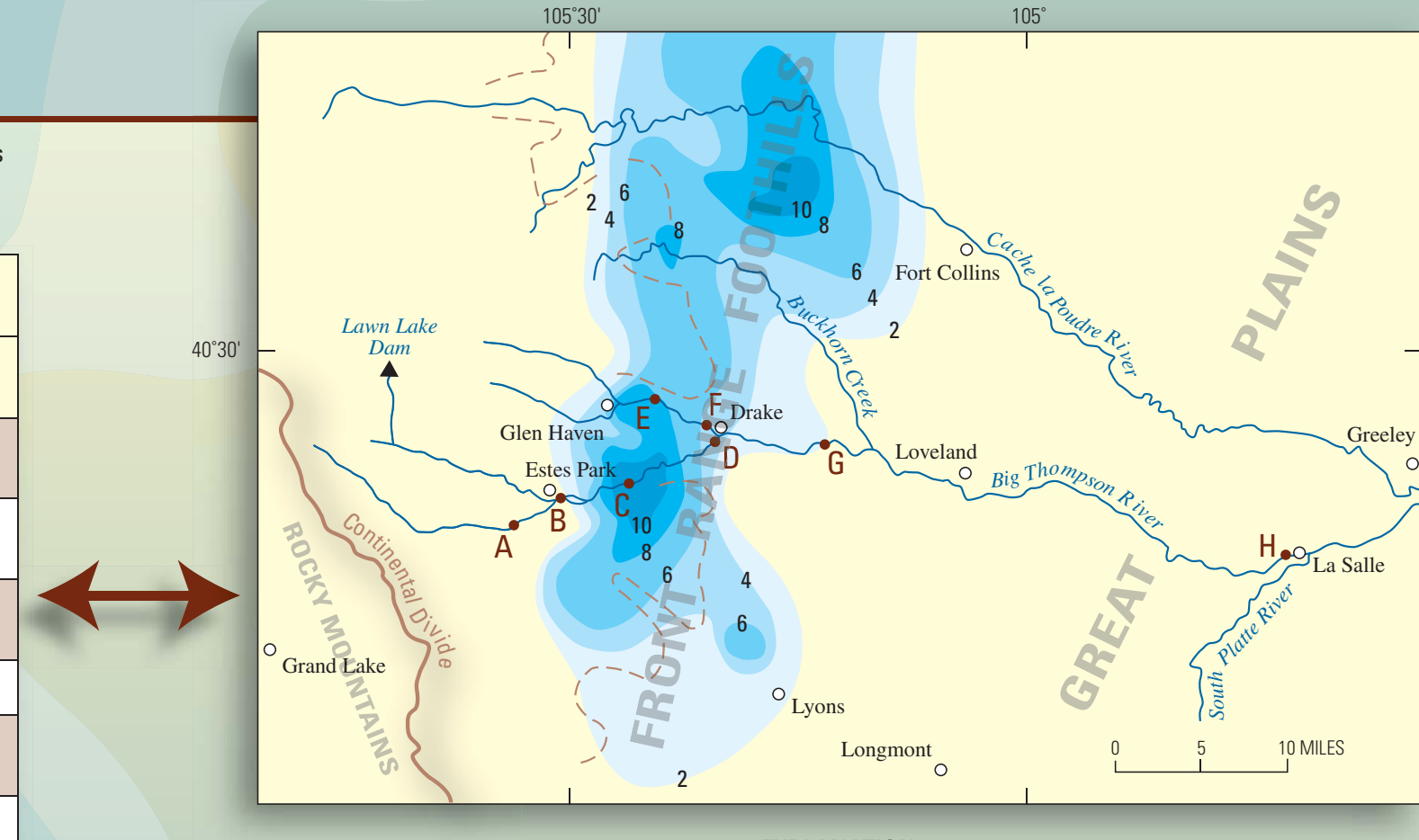

Total rainfall from July 31 to August 1, 1976. Numbers indicate inches of rainfall

Approximate 8,000 foot altitude contour. Datum is mean sea level

-A Location of flood sites in table 1

Figure 3. Sketch map showing measured and estimated total rainfall for the overnight storm of July 31-August 1, 1976. Highest rainfall amounts occurred near 8,000 feet altitude or lower. Stream-gaging stations and selected from U.S. Geological Survey (1979). 


\section{(2)}

- The Big Thompson flood caused geologists to look at the stratigraphy of sediment deposits in the canyon, and from them to try to interpret the occurrence and frequency of paleofloods, particularly in ungaged basins, and to use such information to better understand rare floods such as the Big Thompson flood. This work helped foster and improve the methods of the emerging science of paleoflood hydrology to improve the understanding of flood frequency and flood-hazard mitigation (Jarrett and Costa, 1988).

\section{Colorado Flood History}

Flash flooding is just one of three main types of floods in Colorado (Jarrett and Costa, 1988; Collins and others, 1991). Another type is snowmelt flooding, which predominantly occurs in May and June of each year but usually does not produce substantial flooding. A hazard of such flooding is the possibility of being swept away in cold, fast moving water. The third type is long-duration low-intensity rainfall associated with frontal activity. Such rainfall occurs over large areas and can produce widespread flooding in Colorado, particularly in large drainage basins (Collins and others, 1991).

Although rainstorms and flash floods the magnitude of the Big Thompson flood are infrequent in any one location, they are common from May to October in much of Colorado. Other notable catastrophic flash floods in Colorado occurred in July 1896 and September 1938 in the Bear Creek Basin (foothills west of Denver), October 1911 in the San Juan River Basin, June 1921 in the Arkansas River Basin, May 1935 in the Republican and South Platte River Basins, June 1965 in the South Platte and Arkansas River Basins, and July 1997 in Fort Collins (Collins and others, 1991; http://ccc.atmos.colostate.edu/ odie/rain. html). Many smaller thunderstorms produce locally hazardous flashflood conditions each summer. It has been estimated that each year, on average, Colorado experiences at least one-hundred-fifty 100 -year or larger rainstorms, many of which are very localized (N.J. Doesken, Colorado Climate Center, written communication, 2006). Flooding is particularly common in urbanized areas (even in areas with little topography) where impervious areas can produce hazardous flash flooding as suddenly as the 1976 Big Thompson flood, but with as little as a few inches of rain in an hour. Over 100 dam-failure floods have occurred in Colorado, such as the1982 Lawn Lake Dam failure (Jarrett and Costa, 1986). Extremely hazardous flash floods can also occur in recently burned wildland fire areas, which if unburned would not produce substantial flooding during intense rainstorms.

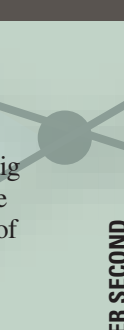

25,000

응

(1)

.

20,000

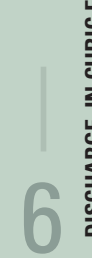

嵌

15

$(10,000$

10,000
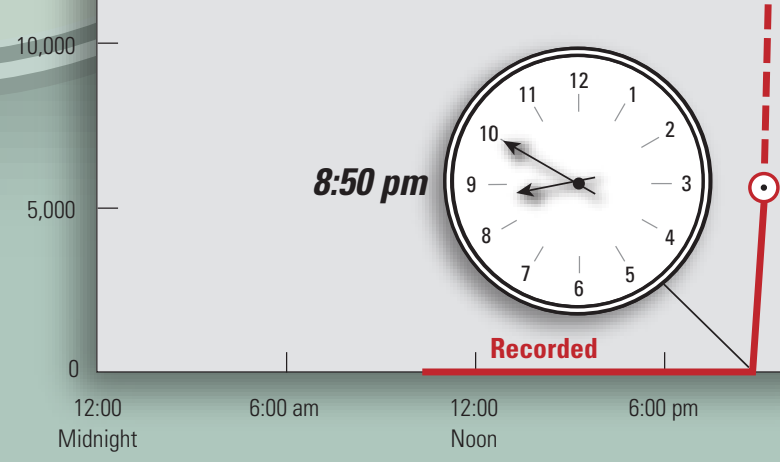

(abic teet per second

$\odot$ observer readings

i

il

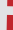

I

I

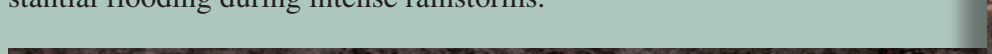

Figure 4. Hydrograph showing the discharge of the Big Thompson River at the mouth of the canyon near Drake (site $\mathrm{G}$ in table 1 and on fig. 3); the hydrograph is estimated because the gage was destroyed by the record flood. Modified from U.S. Geological Survey (1979).

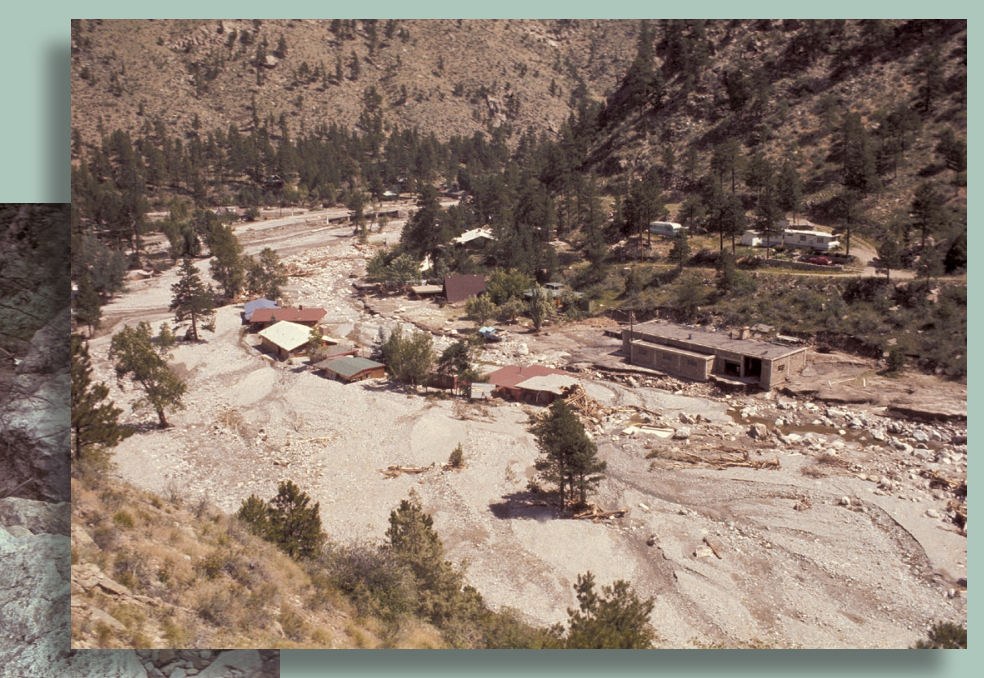

Figure 5 (Above). Damaged and destroyed homes and extensive flood-deposited sediment along the Big Thompson River. This photograph was taken from the hillside looking downstream at Drake. River flow is from bottom right to top center.

Figure $\mathbf{6}$ (Left). Remains of an automobile flattened and wrapped around a large boulder in the North Fork Big Thompson River about 4.5 miles upstream from Drake. River flow is from right to left. The U.S. Army Corps of Engineers removed 197 flood-damaged vehicles in the North Fork Big Thompson and Big Thompson Rivers. 


\section{What to Do Before and During a Flash Flood}

Flash floods can develop with almost no warning. Therefore, it is important to know what to do before and during flash floods.

\section{CLIMB TO SAFETY! IN CASE OF A FLASH॰FLOOD}

\section{BEFORE a flash flood:}

- Identify safe areas in your home or wherever you are located; bring outdoor possessions indoors or secure them if time permits.

- Have a portable 3-day emergency supply kit (such as food, water, medical supplies, clothing, rain gear, portable radio, flashlights, blankets).

- Monitor local radio, television, and National Weather Service (NWS) weather radio for potential adverse weather conditions.

- Be familiar with the NWS's three types of flash flood watches, warnings, and advisories for specific areas: Flash Flood Watch (heavy rains are occurring or expected to occur that could produce flash flooding), Flash Flood Warning (flash flooding is occurring or imminent), and Small Stream and Urban Flood Advisory (minor flooding is occurring or expected that could produce flash flooding).

- Be aware of nature's environmental warning signs (such as dark clouds, heavy rain, wind, and sounds- trees breaking and loud roars).

\section{DURING flash-flood conditions:}

- Stay away from streambeds and other low areas.

- Climb to higher ground and a safer location.

- Don't walk or drive in flooded areas; avoid downed power lines, gas leaks, wild animals, and snakes in and near flooded areas.

- Notify local authorities of flash flooding, if you can safely do so.

\section{(1)}

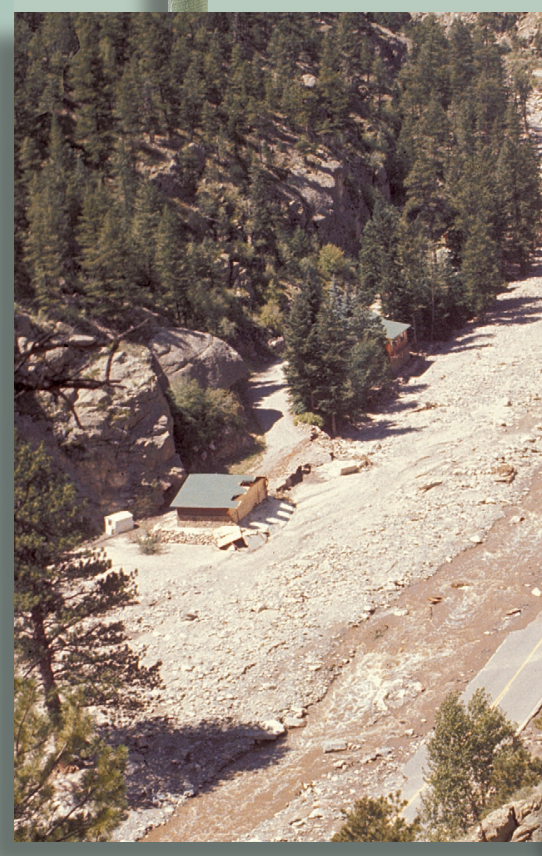

Figure 7 (Above). Upstream view of the Big Thompson River showing extreme flood damage to U.S. Highway 34 upstream from Drake. The U.S. Geological Survey estimated the flood's peak discharge to be 28,200 cubic feet per second in this area.

Figure 8 (Right). This house was built on an alluvial fan that was produced by sediment discharged from a side canyon to the Big Thompson River. Floodwaters from the side canyon damaged part of the house and pushed it about 4 feet off its foundation.

\section{Advances in Flood Protection and Warning}

In the 30 years since the Big Thompson flood, there have been important advances in streamflow monitoring and flood warning. The National Weather Service's (NWS) NEXRAD radar allows real-time monitoring of precipitation in most places in the United States (http:// www.roc.noaa.gov/). The USGS operates 270 real-time streamflowgaging stations on Colorado streams and rivers (http://co.water.usgs. gov/), and the Colorado Department of Water Resources also operates more than 300 real-time gages (http://water.state.co.us/) that are monitored by the USGS, the NWS, and emergency managers. When substantial flooding occurs, the USGS mobilizes personnel to collect streamflow data in affected areas. Streamflow data improve flood forecasting and provide data for flood-frequency analysis for floodplain management, design of structures located in floodplains, and related water studies. Currently (2006), there are nine real-time streamflowgaging stations in the upper Big Thompson River Basin operated by the USGS and Colorado Department of Water Resources.

As a result of the June 1965 South Platte River flood that severely affected the Denver area, the Urban Drainage and Flood Control District (UDFCD) was established for the purpose of assisting local governments in the Denver metropolitan area with multi-jurisdictional

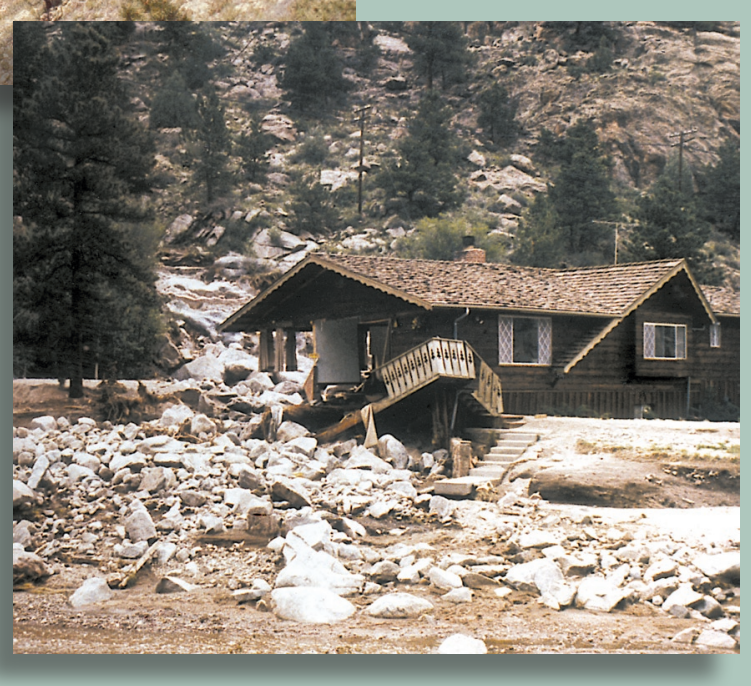
drainage and flood-control problems. The District covers an area of 1,608 square miles that includes about 1,600 miles of major drainageways and serves a population of approximately 2.3 million people. Soon after the 1976 Big Thompson flood, the District set up an early flood detection and local flood warning program. Currently (2006), UDFCD operates an automated flood detection network comprised of 175 ALERT gaging stations (including 152 rain, 87 stream stage, 18 weather). Other large cities such as Fort Collins and Colorado Springs have similar flood warning and floodplain management programs. However, most Colorado streams are ungaged with their flood potential being monitored by the NWS using rainfall-runoff models and flash flood guidance (http://www.noaa.gov). 


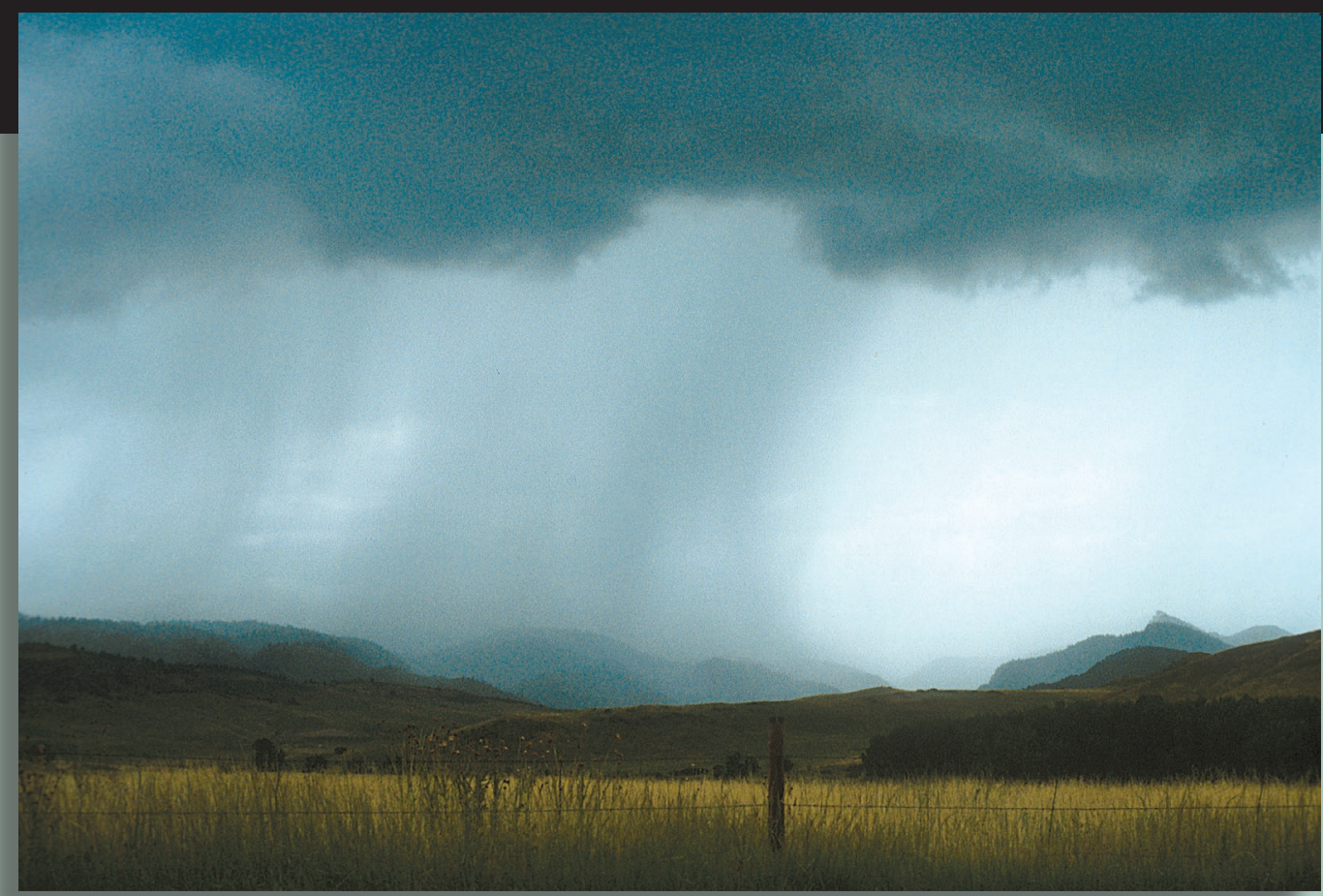

Figure 9. Growing thunderstorm clouds and rain forewarn of potentially severe weather conditions including lightning, intense rainfall, hail, flooding, and tornadoes. Monitoring the development and movement of such clouds, as well as awareness of weather forecasts, can help people prepare for potentially hazardous conditions. Photograph courtesy of Lester Zinser, University Corporation for Atmospheric Research.

Today, flood specialists and emergency responders recognize that awareness of flooding is a combination of weather preparedness and personal responsibility. Before flooding occurs, residents or visitors need to know if buildings are in flood-prone areas, the dangers along stream channels, and if roads may become impassible. In addition, during floods, law-enforcement officials might not be able to drive through flooded areas to provide warnings that people may expect. Flood warnings, such as NWS watches and warnings, UDFCD's ALERT data, and Colorado Department of Water Resources and USGS real-time rainfall and streamflow data, may not be available particularly in remote mountainous areas. Communications may be disrupted during extreme weather events such as floods, tornadoes, and hailstorms.

Nature often provides early warning signs of impending hazardous flooding. Knowledge and observation of developing thunderstorms (fig. 9) can provide important early warning in areas subject to lightning, hail, tornadoes, and flood-producing rains. In some cases, such as during the July 1976 flood in the Big Thompson Canyon downstream from Drake near the canyon mouth, there is little or no rainfall that might alert people that floodwaters are advancing. Once a flood (meteorologic or dam failure) or debris flow begins, many eyewitnesses often mention hearing rumbling sounds (described as trees breaking, jet airplanes, locomotives, and other loud roars) moving closer to their location. A combination of personal responsibility, planning and awareness, National Weather Service and other local flood agency programs and resources, and personal observations of developing weather conditions are vital to prepare people to help protect themselves when hazardous flooding is imminent.

\section{Acknowledgments}

The authors appreciate thorough technical reviews by J.P. Capesius, N.J. Doesken, W.J. Graham, C.A. Perry, K.G. Stewart, and S.J. Vandas, which improved the fact sheet.

\section{References}

Collins, D.L., Doesken, N.J., and Stanton, W.P., 1991, Colorado floods and droughts: U.S. Geological Survey Water Supply Paper 2375, p. 207-214.

Costa, J.E., 1978, Colorado Big Thompson flood-Geologic evidence of a rare hydrologic event: Geology, v. 6, no. 10, p. 617-620.

Costa, J.E., and Jarrett, R.D., 1981, Debris flows in small mountain stream channels of Colorado and their hydrologic implications: Association of Engineering Geologists Bulletin, v. 18, p. 309-322.

Gruntfest, E.C., 1977, What people did during the Big Thompson Flood: Natural Hazards Research and Applications Information Center, Working Paper, 62 p.

Jarrett, R.D., 1987, Peak discharge errors in slope-area computation in mountain streams: Journal of Hydrology, v. 96, no. 1-4, p. 53-67.

Jarrett, R.D., and Costa, J.E., 1986, Hydrology, geomorphology, and dam break modeling of the July 15, 1982, Lawn Lake Dam and Cascade Lake Dam Failures, Larimer County, Colorado: U.S. Geological Survey Professional Paper $1369,79 \mathrm{p}$

Jarrett, R.D., and Costa, J.E., 1988, Evaluation of the flood hydrology in the Colorado Front Range using streamflow records and paleohydrologic data for the Big Thompson River Basin: U.S. Geological Survey Water-Resources Investigations Report 87-4117, 37 p

Jarrett, R.D., and Vandas, S.J. (compilers), 2006, 1976 Big Thompson Flood, Colorado: U.S. Geological Survey General Information Product 35, 1 sheet (poster).

Simons, D.B., Nelson, J.D., Reiter, E.R., and Barkau, R.L., 1978, Flood of 31 July 1976 in Big Thompson Canyon, Colorado: National Academy of Sciences, Washington, D.C., 85 p.

U.S. Geological Survey, 1979, Storm and flood of July 31-August 1, 1976, in the Big Thompson River and Cache la Poudre River Basins, Larimer and Weld Counties, Colorado: U.S. Geological Survey Professional Paper 1115, 152 p.

For more information on USGS science: http://www.usgs.gov; http://water.usgs.gov/osw/; http://ks.water.usgs.gov/Kansas/floodsummary; http://water.usgs.gov/usgs/osw/FS-List-2003.html

For more information on floods and Colorado flood hydrology: http://www.fema.gov; http://www.usace.army.mil; http://www.usbr.gov/pmts/flood/; http://www.udfcd.org/; http://cwcb.state.co.us; http://www.casfm.org; http://floodsafety.org/colorado/index.htm

This fact sheet (FS-2006-3095) and accompanying poster (General Information Product 35) and other publications can be ordered from the USGS Store at http://store.usgs.gov or call 1-888-ASK-USGS (1-888-275-8747).

Authors: Robert D. Jarrett and John E. Costa

Photographs by $\boldsymbol{R}$. D. Jarrett, except as noted otherwise

Edited by F. Craig Brunstein, Denver Publishing Service Center, Graphics and layout by Carol A. Quesenberry, Denver Publishing Service Center 